\title{
Re-Emergence of Cinema Culture in Lagos State: Dynamics and Challenges
}

\author{
Adebisi, Fadhilat Titilayo \\ Department of Mass Communication Fountain University, Osogbo, Nigeria \\ And \\ Adeyemo, Saheed O. Adeyemi \\ Journalism Department Lagos State University Adebola Adegunwa School of \\ Communication,Ojo, Lagos, Nigeria (LASUAASOC)
}

\begin{abstract}
There is something mildly hypnotic about the illusion of movement that holds the attention whenever it comes in close contact to the optic nerves...just like the case of Cinema or motion picture house as it catches attentionat inception. The art of motion pictures had frequently undergone changes that seemed fundamental, such as those resulting from introduction of sound, which is of great difference based on the style adopted from country to country. The paper examines the historical perspective of Cinema Culture from the point of view of the Economic nerve centre of Nigeria, Lagos State.The paper dwells on the trends in the habit of cinema goers in the early $19^{\text {th }}$ century when it all began and how it then evolved over the years in the economic hub of Nigeria as a form of relaxation and entertainment as well as information tools. It further examines the tremendous attitudinal change of the theatre going habit as it forms the factors and variables affecting the Dynamics and challenges of Cinema Culture in Lagos State, regardless of its cosmopolitan population.
\end{abstract}

KEYWORDS: Re-Emergence, Cinema, Culture, Dynamics, Challenges

\section{INTRODUCTION}

According to Encyclopaedia Britannica, a Cinema ormovie theatre is where Motion picture, series of still photographs on films are projected in rapid succession onto a screen by means of light, due to an optical phenomenon known as Persistence of Vision that gives the illusion of actual, smooth and continuous movement. The story of the motion picture started during the pre colonial era in August 12, 1903, when the 'first moving picture was shown to an excited audience at Glover Memorial Hall, Lagos, tagged 'Cinematograph Exhibition' (cited by Adeyemi et al p.176). In these early years, cinema houses were common Cultural Phenomena in Nigeria, especial in Lagos metropolis. Popular films then were India and Chinese films, later came the Americans. Among the popular film houses in Lagos then were Jebaco, Metro and Pen Cinema, etc. Among the early pioneers of the Film Crusade were the Religious organisations. As early as 1907, the Catholic Fathers had started showing film about Jesus to their school audience. By early 1920s, the Cinema was already a popular form of entertainment as well as medium of communication to the local people. However, the cinema business flourished in Lagos which spanned through early nineties till the late 1980s and 1990s. This period, Lagos had more than forty cinema houses (Akarue et al, 1992:37). These Cinemas show variety of favourite films, in which most of them were foreign movies. Among the early films common at the time were: Cinderella (1902), The Great Fight Jefferious, Fitssimous (1902), Egyptian Wonders, etc. By 1939, the then colonialist in power established Colonial Film Unit to raise the standard of living in the areas of; Health, Agriculture, Industry and Education among the people. The motive of this is to complement the commercial cinema in the country and it (Adeyemi et al: p 180)"An important agent in the vast work we have to do in theColonies and we regard it as an important factor creatingin the minds of the people in the Colonies a new sense ofvalues; a contribution for obtaining their cooperation andgoodwill in the great work which has got to be done, and asvital element in breaking through mass ignorance and,illiteracy and in training these people to play a largerpart in the life of their own territories and to help usin the more effective and efficient discharge ofthese responsibilities, we, as British people feel inrespect of the colonial territories under our control"Some critics have argued that productions undertaken in the colonial period were documentaries used to promote the colonial government's policies on Agriculture, Infrastructural development, among other issues. Some Nigerians, including Adamu Halilu, Fajemisin, A.J. Atigba, and Mallam Yakubu Aina, were sent to study in Accra Film Training School, Ghana.”. (Nze, 2010). These trends continued through post independence which saw the Emergence of Nigerian Filmmakers producing domesticated films. Notable among them were: Ola Balogun, Eddie Ugbomah, Hubert 
Ogunde and Adeyemi Adeymi Folayan. Some of the films ran through; Muzikman, the Boy is Good, Oil Boom, Aiye, Jaiyesimi, Aropin N'tenia. As at the turn of 1970 s through ' 80 s and early ' 90 s, the business began to fizzle out due to some factors in which crash crunch and government unfriendly policies topped the list.

Today, the Cinema is striving to gain its confidence back. It is against this background that this study is set to find out what are the major factors responsible for the gradual re-emergence of the cinema culture in Nigeria, especially in Lagos metropolis in the recent time.

\section{LITERATURE REVIEW}

Film is a powerful tool of the mass media, and as such affects our culture consciously and unconsciously (Belton, 2005: Amohi, 2009). Akpan (2002) noted that the traditional objectives of film like other media of mass communication are to inform, educate and to entertain. Akpan says the film ways of achieving the objectives are through specific modes of communication; as drama, feature or documentary. In the words of Enwefah (2009:29), "Film is viewed as an art; a simulation of reality...the ideal of art is to create an illusion of reality, and motion picture is unique in pursuing this ideal". Film combines sound, vision and text, its invention in the 19th century is regarded as an important epoch in the history of cinema in Nigeria.Technically, films are produced by recording images from the world with cameras, or by creating images using animation techniques or special effects. Traditionally, films are made up of a series of individual images called frames. When these images are shown rapidly in succession, a viewer has an illusion that motion is occurring(wikipedia).Culturally; film is often described as the mirror of the society (Frame, n.d; Enwefah, 2009). In his on-line article titled, 'Film and Culture', John M.Frame, citing Harvie (n.d.) described film as a "Cultural Mirror" that reflects contemporary attitude, philosophies, values, and lifestyles". Frame says the relationship between film and culture is a "Chicken-and-egg relationship".Pearson, Nelson, Tisworth and Harter (2003: 212) defined culture as "a system of shared beliefs, values, customs, behaviours and artifacts that the members of a society use to cope with one another and with their world". In the words of Dobkin (2006: 42). "Culture permeates Communicationsituations and significantly influences the Process". Durowade (2001) states that Culture influences individual and at the same time the individual can modify and change the culture.

\section{Mass Media and Cultural Influence}

Mass Communication Scholars hold different views about the existenceor otherwise of media influence (Sparks, 2006; Nordenstreng, 2000; Uche, 2000;Onabajo, 2000). Some studies suggest tha Mass Media are very powerful and as a result exercise immense influence on the audience (Onabajo \& Odoe, 2009). On the contrary, some scholars dismiss the existence of such influence (Spark, 2006). There are others who are of the view that media influence exists at a minimal level (Ogan, 2007). For instance, while citing Bredin (1996), Ogan states that the power of the media to bring cultural change to any ethinic group is quite limited. Ogan, however, states that the difficulty involved in measuring human behaviour is particularly responsible for the divergent views of scholars regarding the effects of mass media products on the audience.Against this backdrop, Scholars have however come to agreement that mass media, particularly audio-visual, are pervasive, reaching virtually all corners of the earth and at the same time, touching the lives of different classes of human race (Sparks, 2006; McQuail, 2005). According to Onabajo and Odoe (2009: 83), "Nobody in the present generation needs a soothsayer to discern that, more than ever, our generation is audio-visual friendly. Scholars alike have come to the conclusion that indeed this is an audiovisual generation. The power of visual and the accompanying audio cannot be qualified. It transcends all ages and cannot be limited by language barrier".

A lot of transformations have accosted the film medium. These transformations make the film medium to be more popular and readily available to the mass audience (Odukomaiya, 2009; Amobi, 2009). For instance with the introduction of television, some feared it would mark the end of film culture. It was not so. Instead, television has helped to develop and popularise the film medium.Film is a major medium through which popular entertainment is made available to the mass audience (Belton, 2005). Mass media researchers seem to agree that entertainment dominates the mass media owing to its mass appeal (Curran, 2002; Stevenson, 2000). The dominance of entertainment film in Nigeria is highlighted by Onabajo and Isiekwenagbu (2009: 129), thus: the home video film has become the most accessible form of popular entertainment to many people in every part of Nigeria.The mass appeal of the media is emphasized by McQuail (2005:118) as he states: " The mass media are largely responsible for what we call either 'Mass Culture' or 'Popular Culture' and they have 'Colonized' other culture of our time... is what flows in abundance by way of media of film, television, newspaper, phonogram, video, and so on". The submission of McQuail underscores the important role the mass media play in shaping the contemporary human culture, Ogan (2007: 294), citing Putnam (1998), captures the central role of the media when he wrote that "Mass media are key components in any nation's culture". According to Ogan, messages carried in mass media shape human culture to the extent that they in turn confront man in different ways. The power of film to influence attitude is believed to be enoumours. M'Bayo and Onabanjo (2009:68) citing Akpabio (2003) state that: "the film medium, combining sound and vision simultaneously, is about the most 
powerful tool of mass communication ever invented by man".Nigerian experience, just like most developing countries, is the same. This is partly due to the history of the medium in the country and partly to globalization process (Alabi, 2000). Akpan (2002:9) describes the origin of film in Nigeria, thus: "The arrival of film in Nigeria came with the colonial government who established a film unit as a part of the information department, meant to spread the British war success during the Second World War'.In his study titled 'Cultrual Imperialism hypothesis revisited' Uche (2000: 49) states: “A number of theoretical perspectives have been proposed for understanding the unidirectional flow of mass mediated cultural products that are mostly entertainment". Uche (2000: 49) also discusses other terms used to describe relationships among differentcultures and they include "cultural synchronization" and "cultural juxtapositioning". Cultural synchronization means an external culture that is welcomed and imitated by another culture which the external eventually supersedes in an evolutionary fashion, while cultural juxtapositioning means placing together of locally produced cultural elements with the externally produced (Uche, 2000)

\section{DISCUSSION}

Film in the country, just as in other parts of the world, is a product of the evolution of older media such as books and theatre (Amobi, 2009). While quoting Adedeji and Ekwuazi (1993), 'TBayo and Alao (2009 : 288) state: " with the current stage in development of the film industry, we are approaching the end of the travelling theatre era. We no longer see those actors we were used to on stage. Their faces are now a constant feature on the screen, on the large screen". Today, this evolution had gone beyond the "large screen" in cinema houses or mobile cinemas (Odukomaiya, 2009).The early film industry in Nigeria was dominated by foreingers and indeed served as a propaganda machine for the colonial authority who exploited the power of the medium to indoctrinate the indigenous people (Onabanjo, 2000). In the words of Alabi (2009: 323), "The government then set up the Colonial Film Unit in 1948 mainly to help boost the weekly attendance of the cinema... the main thrust of the unit was the promotion of colonialization and colonial values. "Onabajo and Odoe (2009) write on how religious organizations take advantage of film, often mobile cinema, to win converts who believed the films they watched as a reflection of real life experience.After years of domination by foreigners, Nigerian pioneer film-makers such Ola Balogun and Eddie Ugboma started charting a new course for the film industry in the country (Odukomaiya, 2009). Their efforts could not last long owing to financial constraints coupled with the introduction of television into many Nigerian homes (Onabajo \& Odoe, 2009; Odukomaiya, 2009).Television itself did not mark the end to film production in the country. Instead, another indigenous generation of filmmakers, such as Kenneth Nnebue, utilized new film technologies to produce films for the thirsty Niegerian audience. Consequently, the production of a film called Living in Bondage in the early 1990s opened the way for what is today known as Nollywood (Amobi, 2009; Onabajo \& Oladapo, 2009).Nollywood has grown to become the third largest film industry in the world after the America's Hollywood and the Indian's Bollywood (Isola, 2009; Alabi, 2009). However, the growth of Nollywood has not helped to reverse the erosion of Nigerian cultural values. Intead it has become an additional tool through which foreign cultures are showcased in the country (M'Bayo \& Onabajo, 2009).M'Bayo and Alao (2009) document that the Nigerian film industry popularly called 'Nollywood' has recorded tremendous growth since the early 1990s. The Scholars still wonders why foreign films still feature prominently in the Nigerian film market. M'Bayo and Alao $(2009 ; 295)$ referred to the study they conducted in 2006 in University of Lagos. In the study, they deduce that many of the Nigerian youths watch more foreign movies than the local ones, and also that more youths believe that Nigerian home videos were inferior to foreign films.

\section{Theoretical Framework}

This research work drawn from theories that describe the kinds and levels of influence or effects that the mass media have on their respective audiences. The theories among others include Psychoanalysis Film Theory, Cultivation Theory, Dependency Theory and Technological Determinism Theory.

Psychoanalysis film Theory: This theory was propounded between 1970s and 1980s with concepts earlier develop by a French psychoanalysis and writer, Jacques Lacan, and was applied to the experience of watching film (http://en.wikipedia.org/wiki/ Psychoanalytical_film_theory). The Theory sees the viewer as the subject of a 'gaze' that is largely 'constructed' by the film itself, where what is on the screen becomes the object of that subject's desire. The Theory stresses the subject's longing for a completeness which the film may appear to offer the viewer through identification with an image. The theory tries to identify the psychological effect films have on audiences. It sees the viewer as being fulfilled with what films presents to him or her. In other words, what the viewer watches on the movie become his heart desire.

Cultivation Theory: this was propounded by George Gerbner et al. The theory states that heavy television viewers will cultivate the perception of reality portrayed by the television (Anaeto, Onabajo \& Osifeso, 2008). According to McQuail (1987: 283), cultivation theory opines that: "television, among modern media, has acquired a central place in daily life that it (TV) dominates our 'symbolic environment' substitituting its messages about reality for personal experience and other means of knowing about the world. The evidence for the theory comes from opinions and attitude which seem to support views that higher exposure to television goes with the sort of world view found in the messages of television. (McQuail,1987). The theory states that the audience sees television messages as the representation of reality or true reflection of their social environment. 
This is so considering the nature of television which combines several media (audio, image and text) thereby depicting life as 'accurate' as possible (Daramola, 2003).

Therefore, Lagos Residence is exposed to cinema culture as:

- Audience spends more than two hours watching films in cinema houses

- Residents still watch film at the theatre.

- Most of the respondents believe that various factors inform their choice of cinema house patronage.

- Most of the respondents are affected one way or the other based on their personal perspective.

Media Dependency Theory:Media dependency theory was propounded by Ball-Rokeach and Melving DeFleur in 1976. The theory opines that the greater dependent an individual is on the media for satisfying his or her desires, the greater important the media will be to that individual www.uky.edu/ -drlane/capstone/ mass/ dependency .htm. According to www.uky.edu, media dependency theory is analyzed thus: this theory is based on the Uses and Gratification Theory and ties into the Agenda Setting Theory. Uses and Grats identifies how people use and become dependent upon the media. People use the media for many reasons; information, entertainment and parsocial relathionships, among others. If someone is so dependent on the media for information, and the media is that person's only or major source of information, then it is easy to set the agenda for such person.

Technological Determinism Theory: This theory was developed in the 1960s by renowned Canadian Scholar, Marshall McLuhan, to explain the role that media technology plays in evolving the culture of the society (Sparks, 2006). McLuhan, stated that dominant media of mass communication shapes human existence. (Akinjogbin \& Odesanya, 2008). He believed that whenever new system of mass communication is invented the society will change in response to the new communication technology (Sparks, 2006).McLuhan saw human history as dominated by four dominant communication modes: acoustic age; literate age; print age, and electronic age (Akinjogbin \& Odesanya, 2008), while writing on McLuhan's view about communication driven changes in society, Sparks (2006:229) quotes McLuhan thus; "The age of electronic communication had arrived. Just as print transformed the old tribal age, so does electronic media would transform the great culture of print". The invention of motion picture has no doubt revolutionized mass communication. Nigerian society today is witnessing a lot of changes in the face of audio-visual media and this development has been variously associated with the seemingly westernization of Nigerian culture (M'Bayo \& Alao, 2009). This is more so owing to the fact that the media technologies and dominant cultures they carry are primarily developed and disseminated from the Western World (Ogan, 2007; Uche, 2000).

\section{Dynamics}

- Audience are exposed to cinemas culture.

- Audience spends more than two hours watching films in cinema houses.

- Not all Residence of Lagos State watch film at the theatre.

- Most of the Respondents believe that various factors inform their choice of Cinema going habit.

- Cinema going culture have good impact on some respondents, while reverse is the case on some others.

Film is a powerful tool of the mass media, and as such affects our culture consciously and unconsciously (Belton, 2005; Amohi, 2009). Film combines sound, vision and text, its invention in the late $19^{\text {th }}$ century is regarded as an important epoch in the history of mass communication (Oloruntola, 2009).Cultural Norm theory provide explanation for selective presentation and tendentious emphasis on certain themes the mass media created the impression amon the audiences that such themes were part of the structur that defined the cultural norms of the society and as a result, impressionable members of the public tend to pattern their own behaviour along the lines of such media presentations (Folarin: 2002). Throughout the history of film industry, gender role stereotyping has normalized dominant cultural values and customs that legitimate male domination of women. As a result, feminist media critics look at film in a range of perspectives. In one aspect, it considers how gender informs norms and values that pattern industry standards, and in turn, how images gender informs norms and values that pattern industry standards, and in turn, how images portrayed in the media reinforce and recreate stereotypes. It also informs the cinema going pattern of the feminists. The emergence of different home video films had also prevented some large number of women in Lagos metropolis from visiting the cinema.The question of stereotyping with regard to sex roles in home video films with men being presented as dynamic and aggressive while women are presented as passive and domestic, men dominate the social space in cinema going habit while women are portrayed as victims of home video watchers.According to Wikipedia's encyclopaedia (2009), cultivation theory suggests that exposure to television overtime, subtly 'cultivates' viewers' perceptions of reality. This combined effect of massive television exposure by viewers' overtime gradually shapes the perception of social reality for individuals and ultimately, this affects our culture as a whole. Gerbner argues that the mass media cultivates attitude and values which are already present in a culture: the media maintain and propagate these values amongst members of a particular culture, thus binding it together. 


\section{REFERENCES}

[1] Aderinokun, T (2005). The economics of nigerian film, art and business. (Online). Available from: http://www.nollywood.net/Essays/p2_articleid/26. (Accessed18 August, 2011).

[2] Akomfrah, J. (2006). On the national in African Cinema(s), In Vital, V. and Willemen, P. Theorizing National Cinema. London: BFI.

[3] Akpabio, E.(2003) African communication system : An introductory text . Lagos: B print publications.

[4] Alabi S.(2009) projecting Nigeria's image through the film industry . In O. Onabanjo \& R. Mbayo (eds), Emergency, Growth And Challenges Of Films And Home Video In Nigeria. Bowie Maryland, USA: African Renaissance Books incorporated.

[5] Allafrica.Com.(2008). Nigeria: Nollywood in retrospect.(Online) Available at http://allafrica. com/ Retrieved May 3, 2011.

[6] Amobi I T. (2009). Perception and implications of the theme of the supernatural in Nigeria's Igbo home video movies. In O. Onabajo \& R.Mbayo (Eds), ), Emergency, Growth And Challenges Of Films And Home Video In Nigeria. Bowie Maryland, USA: African Renaissance Books incorporated.

[7] Asika, N (1991). Research methodology in the behavioural sciences. Ikeja: Longman.

[8] Awani, G. (1997). An introduction to mass communication. Warri: Jenre Publishers. Available from: http//www.google.com, www.encyclopedia.com

[9] Ayanwale. T .B (2001) On effect theatre on university undergraduate in Lagos state university, Unpublished, research project, department of theatre art Lagos state university Ojo, Lagos state.

[10] Bello (1987). Impact of theater performance on the Ibadan residence' a study of Mokola residence. Unpublished. Research project of department of theatre art university of Ilorin, kwara state.

[11] Belton , J . (2005) American, cinema cultural. New York: McGraw- Hill.

[12] Bittner, J. R. (1989) Mass communication: an introduction $\left(5^{\text {th }}\right.$ Ed) new jersey: prentice Hall, Inc.

[13] Black Magazine. (2009.) Available at http://www.thenewblackmagazine.com/view. Retrieved Feb. 17, 2009.

[14] Braston, G. (2000) Cinema and cultural modernity. Buckingham, Philadelphia Open University press.

[15] Brody, N. and Ehrlichman, H. (1997) Personality psychology: Science of individuality. Prentice Hall Press.

[16] Dopkin, B.A, \& pace, R C. (2006) Communication in a changing world. New York:

[17] Durowade, D. (2001). People, Diversity and culture in Nigeria. In L. Olumade \& O. Soyombo, sociology for beginner $\left(2^{\text {nd }}\right)$ Lagos: john west publication.

[18] Ebewo, P. (2007). The emerging video film industry in Nigeria: Challenges and prospects. Journal of Film and Video 59(3):46-57.

[19] Economist.com (2006). Nollywood dream: Nigeria's film industry. Economist.com [Online]. Available at http://www.economist.com/ Retrieved May 3, 2011.

[20] Ekwuazi, H. (2007). The hausa video film: The call of the muezzin. Film International 5(4):64-70.

[21] Enwefah, C. (2009). Film/cinema development: from still to motion picture. In O .Onabajo \& R. Mbayo (Eds) emergence, growth and challenges of films and home videos in Nigeria, Bowie, Maryland, USA: African renaissance books incorporated.

[22] Eysenck, H.J. (1994) Personality: Biological foundations. In P.A. Vernon (Ed.) The neuropsychology of individual differences. London: Academic Press.

[23] Federal Republic of Nigeria. (2007). Official gazette on census population. [Online]. Available from www.nigerianstat.gov.ng/connections/pop2006.pdf. [Accessed 23 March 2009].

[24] Hall, Stuart. (1977). Culture, the media, and the "ideological effect". In Mass Communication and Society, edited by J. Currain. Beverly Hills, CA: Sage.

[25] Haynes, J. (1995). 'Nigerian Cinema: Structural Adjustments' in Research in AfricaLiteratures. Vol. 26. No. 3. African Cinema Autumn. Indiana: University Press. $97-119$.

[26] Haynes, J. (2000). Nigerian videofilms. Athens: Ohio University Center for International Studies.

[27] Haynes. J. (2005). Nollywood: What is in a name. [Online]. Available from: http://www.nollywood.net.vbee/shorthread.php. [Accessed 19 October 2011].

[28] Heck, M.C. (1980). The ideological dimensions of media messages. In Culture, Media, Language: Working Papers in Cultural Studies, 1972-1979, edited by S. Hall. New York: Hutchinson and Co., Ltd.

[29] Kunzler, D. 2007. TheNigerian video industry as an example of import substitution. [Online]. Available from: www.suz.unizh.ch/kuenzler (Accessed 28 August 2011).

[30] Mcquail, D. (2005) Mcquail mass communication theory $5^{\text {th }}$ (Ed) London, California, New Delhi, Singapore: sage publication Ltd.

[31] Mgbejume, O. (1989). Film in Nigeria: Development, Problems and Promises. Nairobi: African Council on Communication Education. Monograph No. 7.

[32] Nigerian Film Corporation (n.d.). Preface on film. [Online]. Available at http://www. nigfilmcorp.com(Retrieved May 5, 2011).

[33] Nwachukwu, F. (1994). Black African Cinema. Berkeley: University of California Press.

[34] Nwachukwu, F. (2003). 'Video Booms and the First Manifestations of 'First' Cinema in Anglophone Africa' in Guneratne, R. and Dissanayake, W. Rethinking Third Cinema. New York and London: Routledge.

[35] Ogunjimi M.O (2004) Introduction to research method and data processing: Lagos, Rayel Communication Limited

[36] Oloruntola. (2009). An overview of the Nigerian film industry. In . O. Onabanjo \& R. Mbayo (Eds) Emergence, Growth and Challenges of Films and Home Videos In Nigeria, Bowie, Maryland, USA: African renaissance books incorporated. 
[37] Olujinmi, B. (2008). The Image of Women in Yoruba Video Films: An Evaluation.Africa through the Eye of the Video Camera. Ed. Foluke Ogunleye. Manzini: Academic Publishers. [Online]. Available at: http:// www.en. wikipedia. org/wiki/History-of- Film.

[38] Osei-Hwere, E. \& P. Osei-Hwere (2008, May 22-26). Nollywood: A multi-level analysis of the international flow of Nigerian video films. Paper presented to the 2008 Conference of the International Communication Association. TBA, Montreal, Quebec, Canada. (Online). Available at http://www.allacademic.com (Retrieved May 3, 2011).

[39] Rotberg, R. (2007). Nigeria: Elections and continuing challenges (Online). Available from:http://www.cfr.org/content/publications/attachments/nigeriacsr27.pdf. [Accessed 28 February 2008].

[40] Saklofske, D. H. \& Zeidner, M.(1995). International handbook of personality and intelligence. New York: Plenum.

[41] Salopek, P. (2005). Nigeriaboasts third-largest film industry in world Nollywood. The Chicago Tribune. [Online]. Available at http://www.chicagotribune.com/

Science. (Retrieved Feb. 7, 2009).

[42] Sunday, A. O. (2009) "An Overview of the Nigerian Film Industry in Onabajo, O and M'Bayo, R, (eds), Emergence, Growth and Challenges of Films and Home .

[43] Tejumaiye J. A (2003) Mass communication research: An Introduction: Ibadan, Sceptre Prints Limited.

[44] Toplin, R. B (1996) History by hollywood: The use and abuse of the american past (Urbana and Chicago: University of Illinois Press,

[45] Umudu. M. (2009). Influence of theater performance on viewing habit of residence of Lagos. Unpublished. Research Project. Lagos state school of communication.

[46] Watkins, Craig S. and Rana A. Emerson. (2000). Feminist media criticism and feminist media practices. Annals of the American Academy of Political and Social Science 